\title{
PENERAPAN KOMUNIKASI TERAPEUTIK OLEH BIDAN \\ KEPADA IBU HAMIL DALAM KEGIATAN ANTE NATAL CARE DI PUSKESMAS JELAPAT KECAMATAN MEKARSARI KABUPATEN BARITO KUALA
}

\author{
H E L M I \\ helmibatola36@gmail.com
}

Pasca Sarjana Ilmu Komunikasi Uniska Banjarmasin

\begin{abstract}
Therapeutic communication is the ability or skill of health workers to help clients adapt to stress, overcome pathological disorders and learn how to connect with others. Therapeutic communication activities mean interaction to facilitate help overcome health problems. The purpose of therapeutic communication to develop the personal client / patient towards a more positive.

This research uses descriptive method of qualitative approach intended to describe, describe, and describe in detail about therapeutic communication form conducted by midwife in orientation phase, working and termination phase and exploring support factor and inhibiting of communication therapeutic to patients in the care of Antenatal care. While the pregnant mother's patients conducted in-depth interviews after receiving Antenatal care service.

The results obtained, the process of Antenatal services at Puskesmas Jelapat Barito Kuala District is in accordance with antenatal care standards that is guided by 10 T. Therapeutic communication conducted midwives to pregnant women patients in providing services Antenatal care at Puskesmas Jelapat Barito Kuala District. therapeutic communication forms performed by the midwife either at the stage or the initial phase (orientation), the working stage and termination stage is interpersonal communication through verbal, written, and nonverbal message delivery. Midwives can identify and describe supporting and inhibiting factors in therapeutic communication. The patient's assessment is conceptually impaired but the patient benefits from therapeutic communication.
\end{abstract}

Suggestion; quality health service needs awareness of Puskesmas Jelapat about the importance of therapeutic communication, all midwives in Puksesmas Jelapat to improve skill or ability in communicating with patient, Puskesmas Jelapat suggested make SOP which firmly, evaluative and responsive especially for therapeutic communication service implementation, preparing a draft of Therapeutic Communication SOP in the ANC service to be submitted to the Puskesmas Leadership

Keywords: Therapeutic Communication, Midwife. Pregnant Women, Antenatal Care (ANC) 


\section{PENDAHULUAN}

Di dalam dunia kesehatan, kegiatan berkomunikasi juga dilakukan oleh dokter dan tenaga paramedis terhadap pasien. Bentuk komunikasi yang sering dilakukan adalah komunikasi interpersonal.Komunikasi terapeutik yang baik dari seorang tenaga profesional bidang medis seperti dokter, perawat maupun bidan, mampu memberikan kepercayaan diri bagi pasien.

Pelayanan antenatal merupakan pelayanan oleh tenaga kesehatan profesional (Dokter spesialis kandungan dan kehamilan, Dokter umum, Bidan, dan Perawat) kepada ibu hamil selama masa kehamilannya sesuai pedoman pelayanan antenatal yang ada dengan titik berat pada kegiatan promotif dan preventif. Pelayanan antenatal disebut lengkap apabila dilakukan oleh tenaga kesehatan dengan frekuensi pelayanan antenatal minimal 4 kali selama kehamilan dengan ketentuan waktu pemberian pelayanan yang dianjurkan yaitu : minimal 1 kali pada triwulan pertama, 1 kali pada triwulan kedua dan 2 kali pada triwulan ketiga.

Ante natal care merupakan perawatan atau asuhan yang diberikan kepada ibu hamil sebelum kelahiran,yang berguna untuk memfasilitasi hasil yang sehat dan positif bagi ibu hamil maupun bayinya dengan mengupayakan hubungan saling percaya bertujuan mendeteksi adanya komplikasi yang dapat mengancam jiwa, mempersipkan kelahiran dan memberikan pendidikan kesehatan.

Bidan adalah seorang wanita yang telah mengikuti dan lulus pendidikan bidan, mendapat izin dan terdaftar secara legal untuk melakukan praktek kebidanan (WHO). Fungsional kebidanan adalah jabatan fungsional khusus termasuk dalam rumpun tenaga kesehatan yang wahana prakteknya meliputi rumah sakit pemerintah, Puskesmas dan jejaringnya.

Rumusan Masalah: Bagaimana proses pelayanan Antenatal care, komunikasi terapeutik yang dilakukan bidan kepada pasien ibu hamil dan apa saja faktor pendukung dan penghambat dalam komunikasi terapeutik dalam memberikan pelayanan Antenatal care di Puskesmas Jelapat Kabupaten Barito Kuala.

Tujuan Penelitian: Untuk mendeskripsikan bagaimanaproses pelayanan Antenatal care, proses komunikasi terapeutik yang terjadi antara yang dilakukan oleh bidan kepada 
pasien ibu hamil dan mengetahui apa saja faktor pendukung dan penghambat komunikasi terapeutik di Puskesmas Jelapat Kabupaten Barito Kuala.

Manfaat Penelitian: penelitian ini diharapkan berguna dan bermanfaat antara lain: Segi Teoritis, Menambah pengetahuan mengenai komunikasi terapeutik antara bidan dan pasien ibu hamil, segi Praktis, berguna sebagaibahan informasi serta dapat menambah wawasan dan pengetahuan yangberkaitan dengan komunikasi terapeutik di dalam memberikan pelayanan Antenatal care di Puskesmas Jelapat Kabupaten Barito Kuala.

\section{TINJAUAN PUSTAKA}

\section{Penelitian Terdahulu}

Siti Aulia Kharisma Agnena dengan judul "Analisa Komunikasi Terapeutik Dokter Dan Pasien Dalam Meningkatkan Pelayanan Kesehatan Ibu Di Rumah Sakit Aisyiyah Samarinda" tahun 2015 Program Studi Ilmu Komunikasi, Fakultas Ilmu Sosial dan Ilmu Politik,Universitas Mulawarman.Asih Fatri Ansari dengan judul "Hubungan Komunikasi Terapeutik Perawat Anak dan Tingkat Kepuasan Keluarga Yang Anak nya Menjalani Hospitalisasi Di RSUD Al
Ihsan Provinsi Jawa Barat". Tahun 2012, Program Studi Magister Ilmu Keperawatan, Universitas Indonesia.Nina Siti Salmaniah Siregar dengan judul "Komunikasi Terapeutik Dokter dan Paramedis Terhadap Kepuasan Pasien Dalam Pelayanan Kesehatan Pada Rumah Sakit Bernuansa Islami Di Kota Medan”. Tahun 2016, Program Studi Komunikasi Islam Program Pascasarjana Univetas Islam Negeri Sumatera Utara Medan.

\section{LandasanTeori}

- Pengertian dan Definisi Komunikasi Interpersonal .

- Komunikasi Terapeutik sebagai Komunikasi interpersonal

- Tujuan dan Manfaat Komunikasi Terapeutik

- Prinsip Dasar Komunikasi Terapeutik

- Bentuk-bentuk Komunikasi Terapeutik

- Tahapan atau Fase Dalam Komunikasi Terapeutik

- Teknik Komunikasi Terapeutik

- Komunikasi Terapeutik Dalam Pelayanan Kebidanan

- Ante Natal Care (ANC) 


\section{METODE PENELITIAN}

\section{Kerangka Konseptual Penelitian}

Komunikasi terapeutik bidan terhadap pasien ibu hamil diPuskesmas dan jejaringnya adalah proses tahapan komunikasi interpersonal yang sangat penting dalam pelayanan kesehatan. Kualitas komunikasi yang terjalin dengan baik dan efektif pada setiap tahapan komunikasi terapeutik yang terjadi antara kedua belah pihak (antara bidan terhadap pasien, dan sebaliknya) akan menghasilkan kemampuan dalam diri pasien dalam upaya mempersiapkan kelahiran.

Alur Pikir

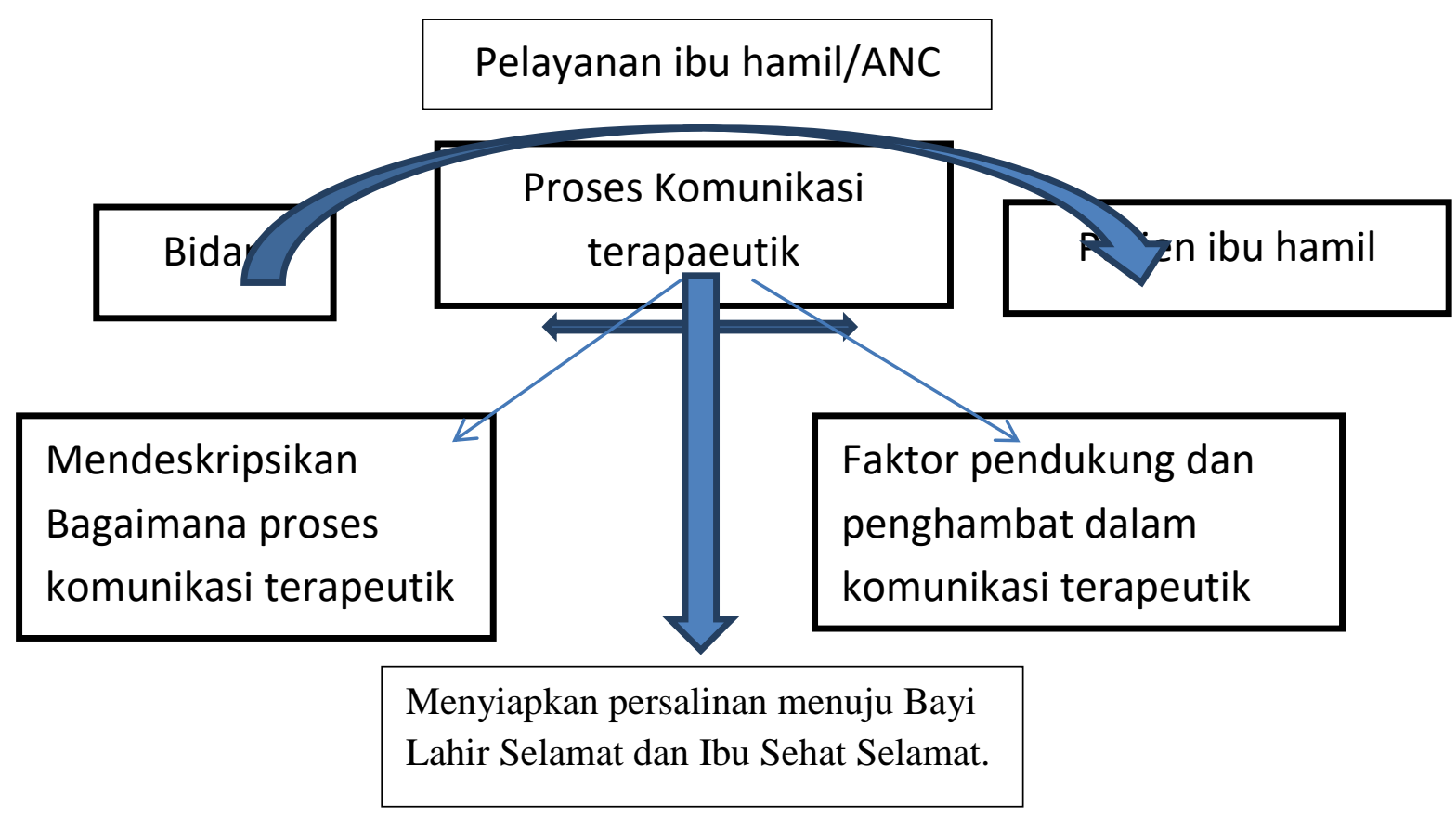

Bagan 1: Alur pikir penelitian

Rancangan Penelitian: Peneliti menggunakan jenis penelitian ini adalah menggunakan metode deskriptif dalam tesis ini. Metode deskriptif yaitu metode yang dirancang untuk mengumpulkan informasi tentang keadaan dan kondisi yang ditemukan selama penelitian untuk menggambarkan sifat suatu keadaan yang berjalan pada saat penelitian dilakukan dan memeriksa sebab-sebab dari suatu gejala tertentu.

Metode deskriptif dapat diartikan berlangsung. Tujuan utama pula sebagai upaya untuk melukiskan 
variabel demi variabel atau konsep demi konsep, satu demi satu, sebagai prosedur pemecahan masalah yang diselidiki dengan menggambarkan atau melukiskan keadaan subjek dan objek penelitian (bisa orang, lembaga, masyarakat dan lainnya) pada saat ketika penelitian berlangsung berdasarkan fakta-fakta yang tampak atau sebagaimana adanya. Pada umumnya penelitian analisis deskriptif adalah penelitian nonhipotesa sehingga dalam langkah penelitiannya tidak perlu merumuskan hipotesa (Suhasimi Arikunto, 1985:139).

Penelitian dengan menggunakan metode deskriptif pada pendekatan kualitatif dimaksudkan untuk menguraikan, memaparkan, dan menggambarkan secara rinci mengenai bentuk komunikasi terapeutik yang dilakukan bidan pada fase orientasi (orientation), fase kerja (working) dan fase penyelesaian (termination) dan menggali factor pendung dan penghambat komunikasi terapeutik terhadap pasien dalam pelayanan Antenatal care. Sedangkan pasien ibu hamil dilakukan wawancara mendalam sesaat setelah mendapatkan pelayanan Antenatal care.
Penelitian deskriptif ditujukan untuk mengumpulkan data aktual secara rinci yang melukiskan gejala yang ada, mengidentifikasi masalah atau memeriksa kondisi atau praktek-praktek yang berlaku, juga menentukan apa yang dilakukan orang lain dalam menghadapi masalah yang sama dan belajar dari pengalaman mereka untuk menetapkan rencana dan keputusan pada waktu yang akan datang. (Jalaluddin Rakhmat, 2006:23).

\section{Tempat/lokasi Penelitian dan Waktu} Penelitian:

Lokasi Penelitian di empat lokasi yang ada di wilayah kerja Puskesmas Jelapat Kecamatan Mekarsari Kabupaten Barito Kuala berikut :Puskesmas Jelapat, Poskesdes Desa Tinggiran Baru, Poskesdes Desa Tinggiran Tengah, Poskesdes Desa Tinggiran Darat.

Sedangkan waktu penelitian ini dilaksanakan pada awal bulan Pebruari 2018 hingga akhir bulan Aprilt 2018.

Informan: Informan dalam penelitian ini adalah 4 orang bidan bertugas di wilayah kerja Puskesmas Jelapat yang memberikan pelayanan kepada ibu hamil (Ante Natal Care), sedangkan informan ibu hamil yang menerima pelayanan ANC oleh bidan 
sebanyak 8 orang. Pengambilan sumber data menggunakan teknik Accidental Sampling dan total Sampling. Accidental Sampling adalah kegiatan pelayanan yang berlangsung saat dilakukan pengambilan data oleh peneliti.

\section{Definisi Opersional:}

Definisi operasional dalam penelitian meliputi;

- Komunikasi terapeutik adalah kemampuan atau keterampilan petugas kesehatan untuk membantu klien beradaptasi terhadap stress, mengatasi gangguan patologis dan belajar bagaimana hubungan dengan orang lain

- Bidan adalah seorang wanita yang telah mengikuti dan lulus pendidikan bidan, mendapat izin dan terdaftar secara legal untuk melakukan praktek kebidanan di wilayah kerja Puskesmas Jelapat Kabupaten Barito Kuala.

- Pelayanan Antenatal Care (ANC) adalah pelayanan oleh tenaga kesehatan profesional yang diberikan bidan di Puskesmas Jelapat dan Jejaringnya berupa pengawasan/pemantauan sebelum persalinan terutama di tujukan pada pertumbuhan dan perkembangan janin dalam rahim.

- Ibu hamil adalah pasien/klien yang mendapat pelayanan Antenatal Care (ANC) oleh bidan di wilayah kerja Puskesmas Jelapat Kabupaten Barito Kuala.

\section{Uji Validitas:}

Penelitian kualitatif harus mengungkap kebenaran yang objektif, karena itu keabsahan data dalam sebuah penelitian kualitatif sangat penting. Melalui keabsahan data, kredibilitas (kepercayaan) pada suatu penelitian kualitatif dapat tercapai. Di dalam penelitian ini untuk mendapatkan keabsahan data dilakukan dengan triangulasi. Adapun triangulasi adalah teknik pemeriksaan keabsahan data yang memanfaatkan sesuatu yang lain di luar data itu untuk keperluan pengecekan atau sebagai pembanding terhadap data itu (Lexy J. Moleong,2007 :330).

\section{Metode Pengumpulan Data:}

Teknik pengumpulan data yang di gunakan adalah penelitian lapanganmeliputi observasi yaitu pengamatan yang di lakukan untuk mengamati objekpenelitian secara langsung, wawancara yaitu cara yang 
dipakai untuk memperoleh informasi melalui tanya jawab secara tatap muka antara peneliti dengan informan, penelitian kepustakaan yaitu penulis mempelajari dan menggali konsepkonsep yang relevan baik yang berasal dari literatur, Undang-Undang atau peraturan-peraturan yang berhubungan dengan penelitian ini.

Data Primer adalah data yang diperoleh langsung dari lokasi penelitian melalui obsevasi langsung dan dengan indepth interview (wawancara mendalam) terhadap subjek sekaligus informan dalam penelitian. Dalam penelitian ini subjek atau informan yang diwawancarai adalah bidansebagai pelaksana komunikasi terapeutik yang dilakukan kepada pasien ibu hamil dalam meningkatkan pelayanan Antenatal care.

Data sekunder adalah data pendukung data primer yang diperoleh peneliti dari berbagai literatur bacaan atau kepustakaan seperti : jurnal penelitian komunikasi, majalah yang berkaitan dengan medis dan kesehatan, website mengenai pelayanan kesehatan, buku online, dan referensi lainnya yang berkaitan dengan topik penelitian tentang komunikasi terapeutik.
Metode Analisa Data: Metode analisis data yang digunakan adalah deskriptif kualitatif. Setelah data terkumpul hasil obsevasi dan wawancara mendalam dilakukan analisa data. Sehingga penelitian ini berusaha memberikan gambaran dari data-data yang dikumpulkan untuk ditarik suatu kesimpulan mengenai penerapan komunikasi terapeutik yang dilakukan bidan kepada pasien ibu hamil dalam meningkatkan pelayanan Antenatal care di Puskesmas Jelapat Kabupaten Barito Kuala.

\section{HASIL PENELITIAN DAN \\ PEMBAHASAN \\ Deskripsi Puskesmas Jelapat}

Gambaran Umum Puskesmas Jelapat:

Pusat Kesehatan Masyarakat yang dikenal dengan sebutan Puskesmasmerupakan fasilitas pelayanan kesehatan yang menyelenggarakan upayakesehatan masyarakat dan upaya kesehatan perseorangan tingkatpertama, dengan lebih mengutamakan upaya promotif dan preventif,untuk mencapai derajat kesehatan masyarakat yang setinggi-tingginya di wilayah kerjanya.

Payung hukum dalam penyelenggaraan pelayanan di 
Puskesmas antara lain; Undang-undang nomor 36 tahun 2009 tentang kesehatan pasal 4 berbunyi "setiap orang berhak atas kesehatan". Permenkes nomor 75 tahun 2014 tentang Pusat Kesehatan Masyarakat intinya Pembangunan kesehatan yang diselenggarakan di puskesmas mendukung terwujudnya kecamatan sehat. Permenkes nomor 43 tahun 2016 tentang Standar Pelayanan Minimal (SPM) bidang kesehatan dengan 12 Pernyataan Standar Pada Standar nomor 1 berbunyi" Setiap ibu hamil mendapatkan pelayanan antenatal sesuai standar", dalam pelaksanaan pemberian pelayanan antenatal di puskesmas Jelapat Kecamatan Mekarsari harus sesuai dengan pedoman Protap ANC dan SOP KIA-KB.

Geografi :Puskesmas Jelapat terletak di desa Jelapat II Kecamatan Mekarsari dan mempunyai wilayah kerja sebayak tujuh desa yaitu empat desa kecamatan Mekarsari dan tiga desa kecamatan Tamban, dengan luas wilayah kerja $142 \mathrm{~km}^{2}$, dari 7 desa tersebut wilayah kerja Puskesmas Jelapat terdiri dari $106 \mathrm{RT}$.

\section{Demografi:Pertumbuhan}

penduduk, penyebaran penduduk, komposisi penduduk, merupakan modal dasar pembangunan dan sangat berpengaruh terhadap kesehatan masyarakat.Jumlah penduduk wilayah kerja Puskesmas Jelapat ke 7 desa sebesar 23.532 jiwa, dengan 6.776 Rumah Tangga, dan rata - rata 3 jiwa per rumah tangga, dan tingkat kepadatan penduduk 165 jiwa per $\mathrm{km}^{2}$.

\section{Pelayanan}

Kesehatan

Puskesmas Jelapat: Secara umum upaya kesehatan terdiri atas dua unsur utama, yaitu upaya kesehatan masyarakat dan upaya kesehatan perorangan.

\section{HASIL PENELITIAN}

\section{Proses Pelayanan Antenatal}

Berdasarkan observasi langsung dilapanganProses pelayanan antenatal di poskesdes Desa Tinggiran Tengah., Desa Tinggiran Baru. Desa Tinggiran Darat. Pasien ibu hamil kunjungan ke bidan disesuaikan kondisi kehamilan pada jam kerja antara jam 08.00 sampai dengan jam 14.30. hari kerja, apabila ada kesepakatan antara bidan dan Pasien ibu hamil pelayanan antenatal dapat sore atau malam hari.

Proses pelayanan antenatal di Poli Kia Puskesmas Jelapat kunjungan ke bidan disesuaikan kondisi kehamilan pada jam kerja antara jam 08.00 sampai dengan jam 14.30. hari kerja. Dengan 
alur pelayanan Pasien ibu hamil datang ke Puskesmas Jelapat mendaftar diloket selanjutnya diarahkan ke poli KIA untuk dilakukan pemeriksaan. Apabila di perlukan pemeriksaan laboaratorium maka pasien ibu hamil di arahkan ke bagian laboratorium selanjutnya kembali ke Poli KIA. Selanjutnya dilakukan pelayanan Poli KIA apabila pasien diberi obat maka diarah ke apotik. Setelah obat diterima pasien boleh pulang.

\section{Hasil wawancara}

Komunikasi terapeutik yang dilakukan bidan kepada pasien ibu hamil dalam memberikan pelayanan Antenatal care di Puskesmas Jelapat Kabupaten Barito Kuala.

\section{PEMBAHASAN}

Proses Pelayanan Antenatal Care Di Puskesmas Jelapat Kabupaten Barito Kuala.

Pelayanan Antenatal yang berkualitas di Puskesmas merupakan pemeriksaan yang harus dilakukan oleh Bidan Puskesmas pengacu pada standar disebut dengan standar pelayanan antenatal adalah pelayanan yang dilakukan kepada ibu hamil dengan memenuhi kriteria 10T sesuai dengan Permenkes nomor 43 tahun 2016 tentang
Standar Pelayanan Minimal (SPM) bidang kesehatan. ANC adalah pemeriksaan untuk ibu hamil yang meliputi : Anamnesa, dan pemeriksaan Fisik. Dalam melakukan pemeriksaan antenatal, bidan memberikan pelayanan yang berkualitas sesuai standar terdiri dari :

T 1 = Timbang Berat Badan dan ukur Tinggi Badan, T2 = Ukur Tekanan Darah, T3 = Ukur Tinggi Fundus Uteri, Presentasi Janin dan Penilaian Detak Jantung Janin, T4 = Skrining Status Imunisasi Tetanus dan berikan Imunisasi Tetanus Toksid (TT), T5 = Beri Tablet tambah darah (tablet besi), $6=$ Periksa laboratorium rutin, $\mathrm{T} 7=$ Nilai Status Gizi (ukur lingkar lengan atas LILA), T8 $=$ PMTCT (Preven Mother To Cild Tranmition), $\mathrm{T} 9=$ Temu Wicara (konseling) dan $\mathrm{T} 10=$ Tatalaksana /penanganan khusus.

\section{Komunikasi Terapeutik Bidan Kepada Pasien Ibu Hamil \\ Komunikasi merupakan proses yang sangat khusus dan berarti dalam hubungan antarmanusia. Bagi profesi kesehatan khususnya bidan dalam penelitian ini komunikasi menjadi lebih bermakna karena merupakan metoda utama dalam mengimplentasikan proses}


pelayanan ANC. Untuk itu profesi kebidanan memerlukan kemampuan khusus dan kepedulian sosial yang mencakup keterampilan intelektual, keterampilan teknis, dan keterampilan secara interpersonal yang tercermin dalam perilaku 'caring' atau kasih sayang ketika berkomunikasi dengan orang lain atau pasien.

Dari hasil wawancara dengan 4 orang bidan yang menjadi informan, menunjukkan pemahaman yang cukup baik terhadap dasar komunikasi terapeutik.

Sebagaimana menurut Nasir dan Muhith, (2011, h.73) komunikasi terapeutik berfungsi sebagai kegiatan bertukar informasi antara perawat dan pasien yang dilakukan secara sadar dalam rangka proses penyembuhan.Hubungan terapeutik antara bidan dan pasien ibu hamil membentuk dasar bagi asuhan kebidanan berdasarkan wawancara dengan 8 orang pasien ibu hamil yang menjadi informan meskipun secara teoritis mereka tidak memahami secara konseptual komunikasi terapeutik tetapi dapat merasakan manfaat dari komunikasi terapeutik yang diterapkan bidan dalam memberikan pelayanan ANC.

\section{Proses Komunikasi Terapeutik}

Salah satu teoritikus keperawatan paling awal yang mengeksplorasi hubungan pemberi pelayanan kesehatan dan pasien dan komunikasi keperawatan adalah Hildegard Peplau yang mengembangkan Teori Hubungan Interpersonal yang menekankan timbal balik (resiprositas) di dalam hubungan interpersonal antara perawat dan pasien. Teori Peplau menggerakkan pemikiran mengenai keperawatan dari apa yang perawat lakukan kepada pasien menjadi apa yang perawat lakukan dengan pasien, membuat hubungan keperawatan menjadi proses interaktif dan kolaboratif antara perawat dan pasien.

Terdapat 3 (tiga) tahapan atau fase komunikasi terapeutik yang dilakukan dokter dan paramedis terhadap pasien menurut Peplau ( Lisa Kennedy Sheldon, 2010:h.56), yakni :

1) Fase Orientasi atau tahap perkenalan tahap perkenalan atau fase orientasi dilaksanakan setiap kali pertemuan dengan pasien. Tujuan dalam tahap ini adalah melakukan validasi keakuratan data pasien dan rencana yang telah dibuat sesuai dengan keadaan klien saat berjumpa atau terkini, serta mengevaluasi hasil 
tindakan yang telah lalu atau tindakan sebelumnya.

2) Fase Kerja (Working) merupakan inti dari keseluruhan proses komunikasi terapeutik. Tahap kerja merupakan tahap yang terpanjang dalam komunikasi terapeutik karena didalamnya perawat dituntut untuk membantu dan mendukung pasien untuk menyampaikan perasaan dan pikirannya dan kemudian menganalisa respons ataupun pesan komunikasi verbal dan non verbal yang disampaikan oleh pasien. Dalam tahap ini pula perawat mendengarkan secara aktif dan dengan penuh perhatian sehingga mampu membantu klien untuk mendefinisikan masalah yang sedang dihadapi oleh klien, mencari penyelesaian masalah dan mengevaluasinya.

3) Fase Terminasi (akhir pertemuan) merupakan akhir dari pertemuan perawat dan klien. Tahap terminasi dibagi dua yaitu terminasi sementara dan terminasi akhir Terminasi sementara adalah akhir dari tiap pertemuan perawat dan pasien, setelah hal ini dilakukan perawat dan klien masih akan bertemu kembali pada waktu yang berbeda sesuai dengan kontrak waktu yang telah disepakati bersama. Sedangkan terminasi akhir dilakukan oleh perawat setelah menyelesaikan seluruh proses keperawatan.

Pembahasan tentang proses komunikasi terapeutik yang dilakukan bidan terhadap pasien ibu hamil di Puskesmas Jelapat dianalisis berdasarkan 3 (tiga) tahapan atau fase menurut Peplau yaitu:

a. Proses Komunikasi Terapeutik Pada Fase Orientasi (Orientation)

Memulai hubungan awal dengan bidan dan pasien ibu hamil memerlukan keterampilan komunikasi yang unik. Setiap hari manusia berkomunikasi dengan orang-orang di sekitarnya dengan mendengarkan, berbicara, berbagi, tertawa, menenangkan dan memperhatikan. Bidan menggunakan komponen komunikasi dasar ini untuk menciptakan hubungan yang bertujuan membantu kesembuhan pasien.

Berdasarkan hasil wawancara dan observasi peneliti terhadap kegiatan bidan, pelaksanan proses komunikasi pada fase orientasi dilakukan dengan cara bervariasi dimana kemampuan komunikasi pada fase orientasi ini belum merata dan optimal dimiliki oleh setiap baik bidan. Masing-masing bidan memiliki gaya komunikasi yang 
berbeda-beda, ada yang kelihatan hangat dan tulus berbicara, ada yang bertanya sekedarnya. Masih berkaitan dengan fase orientasi antara bidan dan pasien, dari semau pendapat informan hampir sama mereka sehingga dapat disimpulkan bahwa bidan sudah dapat diketahui bahwa pelaksanaan kegiatan yang dilakukan pada fase orientasi ketika pasien datang ke tempat pelayanan ANC Poskesdes, Polindes dan Poli KIA di Puskesmas Jelapat Kecamatan Mekarsari Kabupaten Barito Kuala sudah dilakukan.

\section{b. Proses Komunikasi Terapeutik}

\section{Pada Fase Kerja (Working)}

Tahap kerja adalah tahap melakukan identifikasi terhadap permasalahan yang dihadapi pasien. Kegiatan yang dilakukan adalah ketika bidan bekerja sama dengan pasien untuk mengidentifikasi masalah dan menyusun tujuan spesifik yang berorientasi pada masalah atau keluhan keluhan yang dialami pasien.

Bidan juga berkomunikasi dengan anggota keluarga namun tidak ikut masuk biasa ditemani suami, tidak ikut masuk menunggu diluar, pendapatnya tentang Pelayanan ANC yang dilakukan oleh bidan: cukup bagus memberikan pelayanan terbaik buat px dan memberikan manfaat buat saya.

\section{c. Proses Komunikasi Terapeutik} Pada Fase Terminasi (Termination)

Fase terminasi (akhir) adalah tahap akhir dari setiap pertemuan bidan terhadap pasien. Pada fase ini bidan mendorong pasien untuk memberikan penilaian atas tujuan yang telah dicapai, agar tujuan yang tercapai kondisi yang saling menguntungkan dan memuaskan. Kegiatan pada fase ini adalah penilaian pencapaian tujuan dan perpisahan. Fase ini terbagi menjadi dua, yaitu terminasi sementara dan terminasi akhir. Terminasi sementara adalah akhir dari tiap pertemuan dan akan bertemu lagi sedangkan pasien masih dalam ruang perawatan dirumah sakit. Terminasi akhir terjadi jika pasien akan pulang ke rumah. (M.Taufik \& Juliane,2010; hal 52).

Bidan memberi saran tentang tindak lanjut yang akan dilakukan terhadap kondisi kehamilan ada dalam buku KIA, biasa bidan memberi nasehat, jangan bekerja berat, istirahat cukup makan sayur. Untuk pemeriksaan kesehatan berikutnya biasa ada saran bulan depan periksa lagi. 
Faktor pendukung dan Faktor penghambat dalam komunikasi terapeutik dalam memberikan Antenatal care di Puskesmas Jelapat Kabupaten Barito Kuala.

Faktor-faktor pendukung

komunikasi terapeutik yang dapat di identifikasi pada pelayanan antenatal dalam penelitian ini adalah;Lingkungan, tempat dan waktu yang leluasa untuk melakukan pemeriksaan, kadang pasien ada yang tidak suka bergaul sehingga agak tertutup, ada juga pasien yang sangat tertutup hanya berdua saya, ada pasien yang tidak mau diperiksa kalau ada orang lain, persepsi, pendidikan, pengetahuan dan pengalaman, emosi bisa mempengaruhi pasien bisa salah tanggap, latar belakang budaya, prilaku atau kebiasaan dalam masyarakat, latarbelakang sosial (ekonomi yang baik biasanya pasien lebih aktif), kepedulian dengan kehamilan, peran keluarga, peran sesuai dengan keadaan dan bahasa yg digunakan.

Adapun yang menghambat komunikasi terapeutik dalam pelayanan antenatal adalah Pendidikan dan kebiasaan pasien, kepribadian pasien, Pasien ada yang tidak suka bergaul sehingga agak tertutup, persepsi pasien, keyakinan palsu yang tidak sesuai dengan kondisi yang dialami pasien, pasien menurut budaya lama, pengalaman pasien biasanya dikaitkan dengan teori dengan mitos yg dipercayai masyarakat, bertahan dengan keyakinan nya, pasien yang tidak mendengar dengan aktif, pasien mendengar dengan tidak memperhatikan, bidan sendiri mendengar dengan tidak memperhatikan sibuk dengan Hp bahkan tidak ada respon sama sekali, mengubah subjek atau topic, pasien tidak terarah dalam menyampaikan keluhan sehingga sulit menggali permasalan yang dihadapi nya dan sulit merencanakan pemecahan masalah dan pasien yang tidak/kurang konsentrasi, pasien tidak fokus dalam menyampaikan keluhan sehingga bidan sulit menggali permasalan yang dihadapi nya dan sulit menyepakati pemecahan permasalan yang akan dipilih.

\section{KESIMPULAN}

Berdasarkan hasil penelitian yang dilakukan dengan menggunakan observasi, wawancara dan dokumentasi pada Puskesmas Jelapatdan jejaring yaitu Poskesdes Desa Tinggiran Baru, Poskesdes Desa Tinggiran Tengah, Polindes Desa Tinggiran Darat dapat diambil beberapa simpulan sebagai berikut : 
Sesuai dengan penelitian yang telah dilakukan, proses pelayanan Antenatal care di Puskesmas Jelapat Kabupaten Barito Kuala sudah sesuai dengan standar pelayanan antenatal yaitu berpedoman pada 10 T. Bentuk komunikasi terapeutik yang dilakukan bidan baik pada tahap atau fase awal (orientasi), tahap kerja (working) dan tahap terminasi adalah komunikasi interpersonal melalui penyampaian pesan secara verbal, tertulis, dan nonverbal.

Pada fase orientasi atau tahap awal dari hasil observasi dan wawancara yang dilakukan diperoleh temuan bahwa keterampilan atau kemampuan bidan dalam berkomunikasi dengan pasien belum optimal dan belum merata dimiliki setiap bidan.

Pada fase kerja atau tahap working, bidan telah melakukan layanan yang dinilai cukup baik oleh pasien. Namun dari hasil observasi dan wawancara mendalam yang dilakukan diperoleh temuan bahwa komunikasi terapeutik pada fase kerja ini masih belum lengkap sehingga belum optimal.

Pada fase terminasi atau tahap akhir ketika pasien pulang bidan belum sepenuhnya melakukan tahapan yang idealnya harus dilakukan, seperti : kegiatan evaluasi subjektif (pasien diberi kesempatan untuk memberi pendapatnya tentang kepuasannya terhadap layanan asuhan kebidanan) dan kegiatan evaluasi objektif (pasien diberi kesempatan untuk memberi pendapat tentang kepuasannya terhadap kemajuan kesehatannya setelah mendapatkan Pelayanan ANC).

Sesuai dengan penelitian yang telah dilakukan, bidan sudah dapat mengidentifikasi dan mendeskripsikan faktor pendukung dan penghambat dalam komunikasi terapeutik dalam memberikan Antenatal care di Puskesmas Jelapat Kabupaten Barito Kuala.

\section{DAFTAR PUSTAKA}

Ansari, Asih Fatri. 2012. Hubungan Komunikasi Terapeutik Perawat Anak dan Tingkat Kepuasan Keluarga Yang Anak nya Menjalani Hospitalisasi Di RSUD Al Ihsan Provinsi Jawa Barat. Program Studi Magister Ilmu Keperawatan, Universitas Indonesia.

Arwani, 1999. Komunikasi Dalam Keperawatan,Jakarta : Buku Kedokteran EGC

Budyatna, Leilla Mona Ganiem, 2011. Teori Komunikasi Antarpribadi, Jakarta : Kharisma Putra Utama

Burhan Bungin, 2003. Analisis Data Penelitian Kualitatif . Jakarta : PT.Grafindo Perkasa 
ejournal.ilkom.fisip-

unmul.ac.id/.../EJOURNAL\%20

NEW\%20(03-02-15-06-42-

49)(Siti Aulia Kharisma Agnena, 2015. Analisa Komunikasi Terapeutik Dokter Dan Pasien Dalam Meningkatkan Pelayanan Kesehatan Ibu Di Rumah Sakit Aisyiyah Samarinda. Program Studi Ilmu Komunikasi, Fakultas Ilmu Sosial dan Ilmu Politik, Universitas Mulawarman)

HAW Widjaja,2005, Ilmu Komunikasi, Pengantar Studi..Jakarta : Rineka Cipta

http://www.dianrantnaningsih.blogspot,

Diunduh pada tanggal 27 September 2017

Jalaluddin Rakhmat, 2001. Psikologi Komunikasi. Penerbit PT. Remaja Rosda Karya. Bandung Jalaluddin Rakhmat, Metode Penelitian Kualitatif ,Bandung : PT Remaja Rosda Karya.

Joseph A. Devito,1997, Komuniikasi Antar Manusia, Alih Bahasa : Agus Maulana, Jakarta :Professional Books.

Littlejohn ,Stephen.W and Foss, Karen A, 2009.2 Teori Komunikasi:Theories of Human Communication. Jakarta: Salemba Humanika.

Moleong, J., Lexy, 2007. Metodologi Penelitian Kualitatif. Penerbit Remaja Rosda Karya. Bandung.

Mulyana Deddy,2013. Metodelogi Penelitian Kualitatif (cetakan ke8). Bandung:Remaja Rosdakarya.

Mulyana Deddy,2014. Ilmu Komunikasi: Suatu Pengantar (cetakan ke-18). Bandung:Remaja Rosdakarya.

Nursalam. 2003. Konsep dan Penerapan Metedologi Penelitian. Jakarta: Salemba Medika.

P.A. Potter, A.G. Perry, 2005. Buku Ajar Fundamental Keperawatan ,
Konsep, Proses danPraktik, Edisi 4, Volume 2, Alih Bahasa : Renata Komalasari ,dkk. Jakarta : EGC

Peraturan Menteri Kesehatan Nomor 43 Tahun 2016 Tentang Standar Pelayanan Minimal (SPM) Bidang Kesehatan.

Peraturan Menteri Kesehatan Nomor 75 Tahun 2014 Tentang Pusat Kesehatan Masyarakat.

Priyanto Agus, 2009. Komunikasi Dan Konseling, Jakarta : Salemba Medika

Purwanto, H, 1998. Komunikasi Untuk Perawat Jakarta : EGC

Puskesmas Jelapat . 2016. Laporan tahunan tahun 2016. Tidak diterbitkan

Salmaniah, Nina Siti Siregar. 2016. Komunikasi Terapeutik Dokter dan Paramedis Terhadap Kepuasan Pasien Dalam Pelayanan Kesehatan Pada Rumah Sakit Bernuansa Islami Di Kota Medan. Program Studi Komunikasi Islam Program Pascasarjana Univetas Islam Negeri Sumatera Utara Medan.

Sheldon Lisa Kennedy ,2010 Komunikasi Untuk Keperawatan Erlangga. Jakarta.

Suhasimi Arikunto, 1985. Prosedur Penelitian. Jakarta : PT Bina Aksara

Suryani, 2005. Komunikasi Terapeutik Teori Dan Praktek,Jakarta : EGC

Undang-undang RI nomor 36 tahun 2009 tentang Kesehatan.

Veronica Komalasari, 2002. Peranan Informed Consent Dalam Perjanjian Terapeutik Bandung: Aditya Bandung,

Widjaja,2005, Ilmu Komunikasi, Pengantar Studi.Jakarta : Rineka Cipta 